\title{
Adult Germ Cell Tumor
}

National Cancer Institute

\section{Source}

National Cancer Institute. Adult Germ Cell Tumor. NCI Thesaurus. Code C114777.

A germ cell tumor that occurs during adulthood. 